BAHTERASIA 1 (1) (2020)

Bahterasia: Jurnal Ilmiah Pendidikan Bahasa dan Sastra Indonesia

http://journal.umsu.ac.id/sju/index.php/bahterasia

\title{
PERLAWANAN PEREMPUAN DALAM NOVEL RARA MENDUT: ANA-LISIS SOSIOLOGI SASTRA
}

\section{Syafriani Tio Sari ${ }^{\bowtie}$, Silvana Sinar, dan Rudy Sofyan}

Program Studi Magister Linguistik, Fakultas Ilmu Budaya, Universitas Sumatera Utara, Indonesia

\begin{tabular}{|c|c|}
\hline Info Artikel & Abstrak \\
\hline $\begin{array}{l}\text { Sejarah Artikel: } \\
\text { Diterima } \\
\text { Oktober } 2019 \\
\text { Disetujui } \\
\text { Desember } 2019 \\
\text { Dipublikasikan } \\
\text { Februari } 2020\end{array}$ & $\begin{array}{l}\text { Penelitian ini menggunakan pendekatan sosiologi sastra dalam mencari fakta sosial pada novel Rara } \\
\text { Mendut dengan latar belakang tokoh Rara yang berani melakukan perlawanan, menuntut kesetaraan } \\
\text { gender dan mengambil keputusan. Atas keberaniannya, Rara dianggap sebagai pejuang emansipasi wanita. } \\
\text { Metode yang digunakan adalah metode hermeneutik. Pengumpulan data dilakukan dengan teknik baca } \\
\text { dan teknik catat. Hasil penelitian menunjukkan bahwa fakta sosial yang melatarbelakangi tokoh Rara } \\
\text { adalah lingkungan, stratifikasi sosial, dan ekonomi. Fakta lingkungan adalah iklim dan geografis daerah } \\
\text { pesisir atau pantai yang menjadi tempat tinggal Rara. Fakta stratifikasi sosial dapat dilihat dari tokoh Rara } \\
\text { yang hanya seorang nelayan. Fakta ekonomi masyarakat pantai jelas tergambar dalam novel Rara Mendut } \\
\text { yang tergolong memiliki ekonomi lemah. Ketiga fakta sosial tersebut mampu menggambarkan tokoh Rara } \\
\text { yang masih muda namun berani melakukan perlawanan dan penolakan. }\end{array}$ \\
\hline
\end{tabular}

Kata-kata Kunci: perlawanan perempuan, fakta sosial, Rara Mendut, sosiologi sastra

\begin{abstract}
This study uses a literary sociology approach in finding social factsin Rara Mendut's novel with a background in Rara"s character who dares to fight, demandsgender equality and makes decisions. For his courage, Rara is considered as a warrior for women's emancipation. The method use hermeneutic. Data collection is done by reading techniques and note taking techniques. The results of the study show that the social facts behind Rara's character are environment, social stratification, and economy. Environmental facts are the climate ang geography of the coastal or coastal areas where Rara lives. The facts of social stratification can be she from the figure of Rara who is only fisherman. The ecomonic facts of the coastal community are clearly illustrated in Rara Mendut's novel which is classified as having a weak economy. Three social facts are able to describe Rara's young figure who dared to resist and reject.
\end{abstract}

Keywords: women's resistance, social facts, Rara Mendut, Sociology of literature

(C) 2020 Universitas Muhammadiyah Sumatera Utara

\begin{tabular}{lr} 
Alamat korespondensi: & p-ISSN xxxx-Xxxx \\
Kampus UMSU Jalan Kapten Muchtar Basri No 3, & e-ISSN xxxx-Xxxx \\
Medan-Sumatera Utara, 20238 & \\
e-mail: jurnalbahterasia@umsu.ac.id. & \\
\hline
\end{tabular}




\section{PENDAHULUAN}

Proses kreatif pengarang dalam menciptakan karya sastranya dikatakan baik apabila mampu menggambarkan dan mengimplementasikan kondisi masyarakat pada zamannya. Wellek dan Warren (1989:276) mengatakan bahwa karya sastra adalah hasil ciptaan pengarang yang menggambarkan segala peristiwa yang dialami masyarakat didalam kehidupan sehari-hari. Karya sastra seorang pengarang mengandung kebenaran yang mendramatiskan hubungan-hubungan antarmasyarakat berdasarkan pengalaman dan pengamatannya terhadap kehidupan. Namun, hal itu dilakukan secara eleksif dan dibentuk sesuai dengan tujuannya sekaligus memasukkan unsur hiburan dan penerangan terhadap pengfalaman hidup manusia. Betapa pun syaratnya pengalaman dan permasalahan kehidupan yang ditawarkan, sebuah karya fiksi haruslah tetap merupakan cerita yang menarik. Tentu saja karya sastra harus bersifat menarik, sastra harus memiliki struktur dan tujuan estesis, koherensi keseluruhan, dan efek tertentu.

Menurut Stanton (2007:90) novel mampu menghadirkan perkembangan satu karakter, situasi sosial yang rumit, hubungan yang melibatkan banyak atau sedikit karakter, dan berbagai peristiwa ruwet yang terjadi beberapa tahun silam secara mendetail. Ciri khas novel ada pada kemampuannya untuk menciptakan satu semesta yang lengkap sekaligus rumit.

Selain di dunia empiris, diskriminasi perempuan juga dapat terjadi di dunia sastra. Betapa tidak, karya sastra merupakan refleksi dari keadaan masyarakat, kehidupan sosial, dan budaya manusia setempat. Masalah-masalah inilah yang saat ini masih dibicarakan. Hal ini juga tergambar dalam novel Rara Mendut. Seperti dalam kutipan novel dibawah ini.

"Tadi den Rara sudah melampaui batas. Mereka marah." (hlm.119). Kutipan lain yang memperkuat pernyataan itu yakni: "Hitam mata di sudut mengerling kepada Ni Semangka, Mendut berkata tegas, "Apa cuma orang tinggi yang boleh marah?" (hlm.119).

Rara Mendut adalah salah satu novel sejarah karya Mangunwijaya, peneliti mengambil versi ini karena versi ini lebih bersifat kritis, tidak menelan mentah-mentah cerita rakyat yang ada pada masyarakat. Mangunwijaya atau Yusuf Bilyarta Mangunwijaya, PR. (lahir di Ambarawa, Kabupaten Semarang, 6 Mei 1999), dikenal sebagai rohaniawan, budayawan, arsitek, penulis, aktivis dan pembela wong cilik (bahasa jawa untuk "rakyat kecil"). Ia juga dikenal dengan panggilan populernya, Rama Mangun (atau dibaca "Romo Mangun" dalam bahasa Jawa).

Rara Mendut, budak rampasan yang menolak diperistri oleh Tumenggung Wiroguno demi cintanya kepada Pronocitro. Dibesarkan di dusun Telukcikal, kampung nelayan pantai utara Jawa, Mendut tumbuh menjadi gadis yang trengginas dan tak pernah ragu menyuarakan isi pikirannya. Sosoknya dianggap menyimpang dari tatanan di lingkungan istana di mana perempuan diharuskan bersikap serba halus dan serba patuh. Tetapi ia tidak gentar. Baginya, lebih baik menyambut ajal di ujung keris Sang Tumenggung daripada dipaksa melayani nafsu panglima tua itu.

Sastra bersumber dari kenyataan yang berupa fakta sosial. Di dalam novel Rara Mendut diceritakan tentang perlawanan gender, kesetaraan gender dalam mengambil keputusan, melawan perintah raja dsb. Rara dianggap sebagai penentang dominasi 
patriarkis, pejuang emansipasi perempuan. Jadi peneliti tertarik untuk meneliti fakta sosial yang melatarbelakangi perlawanan yang dilakukan oleh tokoh Rara yang terdapat dalam novel Rara Mendut.

Pendekatan terhadap sastra yang mempertimbangkan segi-segi kemasyarakatan itu disebut sosiologi sastra dengan menggunakan analisis teks untuk mengetahui strukturnya yang kemudian dipergunakan memahami lebih dalam lagi gejala sosial yang di luar sastra (Damono, 2002:3).

Bagi Taine, sastra bukanlah sekedar permainan imajinasi yang pribadi sifatnya, tetapi merupakan rekaman tata cara zamannya, suatu perwujudan macam pikiran tertentu. Novel, misalnya, adalah cermin yang bisa dibawa kemana pun-dan paling cocok untuk memantulkan segala aspek kehidupan dan alam.

Taine menentukan sebab-sebab yang menjadi latar belakang timbulnya sastra besar.Ia mengajukan tiga konsep: ras, saat, dan lingkungan (millieu). Dalam tulisan-tulisan Taine ternyata lebih tertarik untuk membicarakan konsep ketiga, yakni lingkungan. Teori lingkungan ini mencoba memberi penjelasan tentang asal-usul sastra. Iklim dan geografi mempunyai pengaruh penting terhadap sastra (Damono, 1984:19-20).

Dengan menerapkan teori sosiologi sastra penggambaran suatu masyarakat di dalam karya sastra akan diketahui dengan jelas. Selain itu dengan sosiologi sastra karya dapat dikaji dengan memfokuskan perhatian kepada segi-segi sosial kemasyarakatannya.

Fakta sosial hakikatnya adalah mempengaruhi tindakan manusia. Tindakan individu yang merupakan hasil proses pendefinisian realitas sosial serta bagaimana orang mendefinisikan situasi, asumsi yang mendasari bahwa manusia adalah makhluk yang kreatif dalam membangun dunia dan sosialnya sendiri. Menurut Durkhiem fakta sosial adalah cara bertindak, berpikir, serta berperasaan yang berda di luar individu dan mempunyai kekuatan memaksa. Fakta terdiri dari kenyataan yang disusun oleh suatu materi-materi yang saling berhubungan dalam bentuk interaksi antar manusia, jadi sifatnya independen dan subjektifitas manusia.

Tujuan penelitian ini adalah untuk menganalisis fakta sosial dalam novel Rara Mendut. Berdasarkan fakta sosial tersebut akan dilihat perjuangan Rara dalam melawan kesewenangan penguasa.

\section{METODE PENELITIAN}

Penelitian ini menggunakan metode hermeneutik. Hermeneutik adalah pendekatan yang lebih menekankan keterlibatan seorang menafsir terhadap objek yang diteliti. Hermeneutik mengutamakan pemahaman dan interpretasi peneliti terhadap objek penelitian. Penelitian ini bermaksud untuk memahami fenomena yang dialami oleh subjek penelitian misalnya perilaku, persepsi, motivasi, tindakan dan lain-lain dengan cara mendeskripsikan dalam bentuk kata-kata dan bahasa, pada suatu konteks khusus alamiah dan dengan memanfaatkan berbagai metode ilmiah. Sumber data dalam penelitian ini adalah novel Rara Mendut karya Y.B.Mangunwijaya tahun 2008 penerbit PT Gramedia Pustaka Utama.

Teknik pengumpulan data menggunakan teknik baca dan teknik catat. Metode analisis data yang digunakan dalam metode penelitian ini adalah metode deskriptif, yaitu 
mendeskripsikan data secara sistematis kemudian dilanjutkan dengan penganalisisan data berdasarkan masalah yang ditawarkan yaitu mengenai fakta sosial yang diakhiri dengan simpulan.

\section{HASIL PENELITIAN DAN PEMBAHASAN}

Dalam novel Rara Mendut terdapat fakta sosial yang hakikatnya adalah mempengaruhi tindakan manusia. Tindakan individu yang merupakan hasil proses pendefinisian realitas sosial serta bagaimana orang mendefinisikan situasi, asumsi yang mendasari bahwa manusia adalah makhluk yang kreatif dalam membangun dunia dan sosialnya sendiri. Berikut adalah fakta sosial yang terdapat dalam novel Rara Mendut yang melatarbelakangi tokoh Rara untuk melakukan perlawanan dalam kesetaraan gender .

\section{Lingkungan}

Taine mengatakan bahwa iklim dan geografi mempunyai pengaruh penting terhadap sastra. Dalam novel Rara Mendut diceritakan bahwa tokoh Rara adalah seorang masyarakat pantai kampung nelayan Telukcikal. Terlihat dalam kutipan berikut:

"Mendut, anak pantai, persentuhan darat, laut, dan udara!" (hlm.32)

Secara demografi, masyarakat pesisir dianggap berkarakter keras, tegas dan tidak mudah diatur menjadi sebuah ciri masyarakat pesisir dalam berinteraksi dan berkomunikasi dengan orang lain. Tentunya, masyarakat pesisir juga mempunyai gaya atau model sendiri dalam berkomunikasi dengan orang lain, maupun orang luar wilayah pesisir. Walaupun demikian, masyarakat pesisir tetap menjadi bagian dari masyarakat Indonesia yang masih mempertahankan budaya dan tradisi pesisiran.

Berikut ini adalah kutipan-kutipan yang membuktikan pernyataan di atas:

"Oh! "Menyembahlah Mendut, tetapi sama sekali tidak rapi, mata tetap melirik pada Nyai Ajeng. Nyai Ajeng, penuh perhatian, toh tersenyum juga melihat kepolosan lucu itu. "Dapat menari kau, Mendut?" Ni Semangka langsung mencegat penjurusan yang dapat merepotkan segala-galanya, "Ooooh, maafkan, tidak bisa, Bendara Ayu Ajeng. Den Rara ini anak pantai yang belum lama di Kadipaten Pati. "Mendut memprotes galak, "Bisa saja!"

"Bisa?" Tanya Nyai Ajeg heran campur kecewa.

"Atas satu syarat."

Terkejut mendesislah Ni Semangka, "Den Rara Mendut!”

Nyai Ajeng jengkel, tetapi tak berbeda.

"Biar dia bicara. (kepada Mendut) Apa?

"Sesudah puas melihat Mataram ini, saya minta dikembalikan lagi ke rumah ibu saya." (hlm.82)

Rara Mendut sebagai anak pantai memberontak melakukan perlawan. Hal ini tergambar juga dalam kutipan dibawah.

“.....................tetapi Mendut ini? Dia hanya tegak berdiri, kainnya di-cincing-kan sampai diatas lututnya, menendang, menampar, melawan seperti harimau betina membela anaknya............." 
Sebab setiap kali tangan mereka menjamah tubuh mendut, kaki sang gadis menggenjot perut; tangan menampar muka; dan tidak peduli kainnya sobek moratmarit lepas setengah telanjang, si harimau pedang-pedang pantai itu menampar, menyepak, menggarut begitu sengit, sehingga mereka terpaksa mengalah daripada kelak ditertawakan............" (hlm.33)

Rara Mendut juga tidak ingin dipaksa dalam hal pernikahan, padahal banyak wanita lain yang ingin dipersunting Tumenggung yang kuasa dan kaya, hal ini terlihat dalam kutipan novel berikut.

“......Kita kan hanya perempuan rampasan belaka, Den Rara. Kenapa Den Rara tidak mau dipersunting Tumenggung yang kuasa dan kaya raya? Kan enak nanti." (hlm.119)

Seperti Rara Mendut yang akhirnya menemukan kebebasan dengan kematian, yang terjadi ketika antarmanusia, Pranacitra dan Wiraguna, terdesak dari manusia lain, mengancam kebebasannya atau membuat orang lain sebagai objek yang baku.

Hal ini juga digambarkan dalam kutipan:

Serangan kilat Wiraguna benar-benar menentukan. Pranacitra tergelimpang di depan Rara Mendut walaupun masih sempat menikam Wiraguna, yang terampil mengelakkan serangan. Wiraguna mengamuk untuk kedua kalinya dan penuh napsu menikamkan kerisnya ke arah dada Pranacitra. Tetapi, pada saat itu Mendut maju spontan bermaksud membela kekasihnya. Tanpa segaja keris Wiraguna menusuk jantung Mendut yang rebah di atas kekasihnya. (hlm.277-278)

Rara Mendut adalah perempuan pesisir yang hidup dengan segala kekebasannya, tidak mempermasalahkan apakah pekerjaan itu pantas dilakukan oleh seorang perempuan atau tidak? Yang pasti ia tidak pernah membedakannya. Sebagai bentuk pemikirannya, Rara Mendut berperan sebagai manusia yang berada sebagai manusia yang memiliki kekebebsan yang otonom. Otonom inilah yang menjadikan Rara Mendut sebagai manusia bertransendensi diri sendiri, dapat mengatakan ya atau tidak terhadap segala sesuatu yang dihadapinya.

Hal ini terlihat dalam kutipan novel di bawah ini.

“Ayo, bangun! Ini waktu kerja! Tidak untuk tidur seperti bayi benggala ," ejek Siwa tua. Tertawa gadis itu bangun. Sesudah membenahi kainnya dan membereskan kembalirambutnya yang kacau ke dalam ikatan yang sekarang agak tahu aturan, ia mendekati Siwa-nya, menangkap pergelangan tangannya dan merayu, "Wa, aku ikut kau terus sajalah."

...

"Ikut berlayar cari ikan tadi. Jangan suka menggerutu."

"Ya, itu kan dengan sendirinya."

"Mana dengan sendirinya. Gadis ikut cari ikandi laut."

"Memasak saya bisa juga. Mencuci, membersihkan rumah juga bisa. Nanti Paman dan Bibi saya manja. Tapi saya boleh tinggal di sini saja, ya ... Ayo, Wa, mbok bilang ya, begitu. Kan mudah. Cuma bilang: ya! Baik! Begitu .... (hlm.5-6) 


\section{Stratifikasi Sosial}

Dalam masyarakat Jawa dikenal adanya stratifikasi masyarakat sebagai suatu warisan sistem kerajaan dan sistem feodal penjajah masa lampau. Dua golongan stratifikasi masyarakat yang saling berhadapan tersebut meliputi priyayi-wong lumprah, wong gedhe-wong cilik, pinisepuh-kawulo mudho, santri-abangan, dan sedulur-wong liyo (Endraswara, 2003).

Terlihat dalam kutipan berikut.

“.......Disangka kami disni kaum udik? Orang desa? Gembala gunung?..."(hlm.118)

Kutipan lain juga tergambar kelas-kelas sosial.

“.......nalar para ksatria berkata dengan mata keris. Nalar kaum petani ada dalam sabda tanaman padi. Dan nalar nelayan adalah nalar air."(hlm.135) dan

"Mengapa orang-orang gedhe itu tidak berkelahi saling melarak di tempat jauh sana saja, menjauhi kedamaina kaum pantai yang terus terang saja tidak pernah merasakan hubungan batin serambut pun dengan orang-orang pedalaman, biar berpangkat raja agung sekalipun....." (hlm.10)

Adapun kelas-kelas sosial itu dimungkinkan terjadi karena pengaruh agama, adat, maupun pekerjaan atau mata pencaharian masing-masing masyarakat. Bukti bahwa masyarakat Jawa masih mengenal Kaum Priyayi sebagai kaum elit politik/bangsawan, kaum orang kebanyakan yang terbagi atas tingkat ekonomi ataupun kekayaan serta golongan sudra/kaum melarat sebagai kaum paling bawah terlihat dalam kutipan berikut:

lewat. Kuda Panglima Tumenggung Wiraguna sendiri. Saat itulah pertama
pertemuan pertama antar panglima termasyur Mataram dengan si Mendut. Jelas
tidak cantik molek ketika itu keadaan sang dara lemas. Tumenggung Wiraguna pun
ketika itu hanya menyangka dia perempuan kampung biasa yang sedang di kejar-
kejar salah seorang prajuritnya yang brangasan.......” (hlm.34)
dan
"Mendut anak rakyat jelata, bukan?" (hlm.110)

Selanjutnya yaitu, masyarakat jawa juga di bedakan berdasarkan pangkat atau jabatan, seperti keterangan yang terdapat dalam kutipan berikut:

"Apa itu tadi? Tak ada seorang nelayan pun akan menegrti apa itu Siwa yang tadi spontan ikut juga duduk di pasir bersama perwira-perwira dan prajurit-prajurit serba-merah jingga kencana di sekelilingnya, hanya dapat menoleh ke kanan ke kiri....." (hlm.12)

Berikut kutipan novel Rara Mendut berdasarkat pankat atau jabatan juga terlihat.

"Benar. Pak lurah mengantarkan pasukan itu menuju perahu Siwa." (hlm.10)

Orang kebanyakan juga dipisahkan dari para elit kenegaraan seperti priyayi. Diterangkan dengan kutipan berikut:

“.............sehingga para priyayi yang tadinya pura-pura tidak ingin ikut serta dengan kaum kampungan itu sekarang tergerak untuk melihat............."(hlm.160) dan “ ......bersama dengan priyayi ningrat seluruh kerajaan....." (hlm.53)

Raja, sebagai figur sentral dalam komunitas kerajaan dan masyarakat Jawa pada umumnya, memiliki peranan besar dalam bidang sastra. Dalam novel Rara Mendut digambarkan hanya pada sampai panglima besar Mataram saja karena ia ingin menikah 
dengan Rara Mendut. Melalui karya sastra mereka membentuk pandangan tentang perempuan ideal (Sukri dan Sofwan, 2001:137). Berikut juga terlihat dalam novel Rara Mendut.

"Panglima Besar Mataram manusia ksatria, Nyai Ajeng yang hamba hormati. Dan sabda ksatria selalu dapat diandalkan.” (hlm.117)

Adapun kutipan lain.

"Silakan bertitah, Baginda, uyang oleh para hamba-hamba negeri disebut Agung dan berkenyataan agung." (hlm.68)

Perintahnya yang harus diutamakan juga tergambar dalam kutipan dibawah.

“.............sebab begitulah perintah sang Temenggung: selama berjualan tidak ada seorangpun yang boleh melihat wajah maupun sosok tubuh sang jelita......" (hlm.160)

Rara sebagai tokoh utama digambarkan sebagai masyarakat kecil atau wongcilik. Hal ini dapat kita lihat dari kutipan teks novel dibawah ini.

Mendut berkata tegas, “Apa cuma orang tinggi yang boleh marah?” (hlm.119)

Dapat kita lihat bahwa Rara mengatakan orang tinggi tersebut yang dimaksud adalah raja. Masyarakat Jawa yang diutarakan pengarang lewat novel Rara Mendut masih mengenal tingkatan-tingkatan sosial ataupun golongan-golongan kehidupan sosial.

\section{Ekonomi}

Dalam novel Rara Mendut, digambarkan pula bahwa Rara adalah anak pantai yang tinggal dilingkungan nelayan, memiliki ekonomi lemah. Hal ini bisa dilihat dari kutipan di bawah ini.

" Tetapi mana ada nelayan tidak tampak prihatin. Semalaman mereka harus bergulat melawan angindan gelombang-gelombang buas yang seolah-olah tidak mau berdamai dengan dirinya.....

Tetapi, kekayaan tak ternilai yang mereka nikmati ialah kemerdekaan, cakrawala luas, lagu-lagu haru, deru angin, dan bunyi gairah senggakan merpati-merpati laut." (hlm.3)

Dalam kutipan lain juga tergambar.

" Prajurit krocuk dan abdi istana pun, tak beda dari para nelayan di pantai, sebenarnya sangatlah miskin. Begitu miskin, sampai merokokpun harus bergantian dari satu batang........" (hlm.139)

Tergambar jelas bahwa Rara Mendut adalah gadis miskin karena ia adalah seorang gadis yang tinggal dipantai yang identik dengan kehidupan nelayan. Dari teks di atas dapat kita lihat bahwa Rara adalah orang yang merdeka yaitu bebas, sehingga itu yang mebuat ia bebas dalam bertindak, walaupun mereka mempunyai ekonomi yang memprihatinkan tetapi mereka menikmati kemerdekaan. Ketika Rara Mendut menolak perintah Tumenggung, sehingga Rara dikenai pajak harus membayar sebanyak tiga reyal, padahal ia tahu bahwa Rara tidak akan mampu membayar pajak tersebut. Hal ini terlihat dalam kutipan teks novel di bawah.

\footnotetext{
“..Uang sebanyak itu cari di mana nanti, Den Rara?"

"Tahulah...."

"Sama dengan membunuh begini ini!”....
} 
“Kita harus cari akal. Akal mengalahkan uang Ni Semangka......"(hlm.135)

Tetapi Rara Mendut tidak kehabisan akal ia malah menjual rokok untuk mendapatkan uang sebanyak itu. Rara Mendut merokok merupakan perwujudan dari penolakan untuk memenuhi keinginan Wiraguna untuk menjadikannya selir. Sebagai wanita dari kalangan rakyat biasa, Mendut juga ingin merasakan kebebasan menentukan pasangan hidup. Saat Wiraguna memanggilnya untuk dijadikan sebagai selir, tidak menjadi hal yang menyenangkan karena bukan Wiraguna yang diinginkan Medut sebagai kekasihnya, sekalipun Wiraguna adalah panglima. Namun seolah apa yang dititahkan panglima harus dituruti Mendut.

Sejalan dengan pendapat Handayani (2012: 94) wujud rasa penolakan Rara Mendut yang diperistri oleh Tumenggung Wiraguna disini menunjukkan adanya sifat kemandirian perempuan nusantara. Dengan merokoklah, Rara Mendut menunjukkan perlawanan terhadap kesewenangwenangan Wiraguna. Merokok menjadi simbol perlawanan Mendut terhadap pengekangan terhadapnya. Perlawanan terhadap pihak oposisi yang mengurangi kebebasan dalam menentukan arah hidup. Serta perlawanan terhadap sistem kerajaan, mengenai putri boyongan. Bagi Mendut, sistem putri boyongan adalah hal yang harusnya tidak ada. Kekalahan suatu daerah harusnya bukan berarti keharusan semua wanita daerah tersebut untuk menjadi milik penguasa.

Hal ini terlihat dalam kutipan novel dibawah.

“....Hei esok ekan ada penjual rokok baru. Kinyis-kinyis baru." (hlm.153)

dan "....muncullah layar siluet Rara Mendut yang genit dan memukau. Bayangan Mendut melenggak lenggok mengambil sebatang rokok, lalu bergaya dimasukkan kedalam mulut...."(hlm.157).

Menurut Handchard (Krisnawati, 2018: 8-9) merokok menjadi penanda kekuasaan dari wanita akan dirinya. Wanita yang tidak memiliki kekuatan fisik untuk melawan, justru menggunakan kepiawaian merokok. Melalui rokok wanita mampu menguasai lawan jenisnya. Melalui rokok, wanita menjalankan weapons of the weak, yaitu ketika berada di bawah tekanan, kelompok dominan dengan kedudukan superordinat di dalam pemerintahan, kehidupan sosial, serta ekonomi dan kemiliteran ditaklukan oleh serbuan kelompok subordinat di dalam sistem politik yang justru mendorong jatuhnya hegemoni kepatuhan mutlak kepada kaum dominan, serta jatuhnya kekuasaan kelompok dominan.

\section{SIMPULAN}

Dari uraian di atas, dapat disimpulkan bahwa sosiologi sastra yang terdapat dalam novel Rara Mendut adalah faktor lingkungan, stratifikasi sosial, dan ekonomi. Lingkungan tempat Rara tinggal adalah daerah pesisir pantai. pemikiran masyarakat pesisir lebih maju jika dibandingkan masyarakat pedalaman, karena pesisir merupakan tempat para kapal nelayan berlabuh, sehingga komunikasi sering terjadi. Stratikiasi sosial dalam novel ini menunjukkan bahwa Rara adalah masyarakat kelas bawah atau wong cilik, namun dia bisa mendapatkan suami seorang panglima. Ini membuktikan bahwa Rara adalah perempuan yang memiliki kelebihan. Faktor ekonomi, sebagai seorang anak pantai, Rara tergolong 
masayakat yang ekonominya lemah. Kehidupan yang mandiri membuat Roro tidak mematuhi keinginan tumenggung. Atas tindakannya itu, Rara dikenakan pajak yang sangat tinggi. Untuk membayar pajak tersebut, Rara harus berjualan rokok bahkan dia harus merokok. Merokok merupakan bentuk perlawanan terhadap kesewenangan yang dilakukan oleh penguasa. Fakta-fakta tersebut yang membuat Rara sebagai tokoh emansipasi wanita berani melakukan perlawanan dalam upaya untuk mencapai kesetaraan gender, dan bebas dalam mengambil keputusan.

\section{DAFTAR PUSTAKA}

Damono, S. D.. (1984). Sosiologi sastra sebuah pengantar ringkas. Jakarta: Depdikbud.

Damono, S. D. 2002. Pedoman penelitian sastra. Jakarta: Depdiknas.

Endaswara, Suwardi. 2003. Falsafah hidup Jawa. Yogyakarta: Cakrawala.

Handayani, Abmi. 2012. Perempuan bicara kretek. Jakarta: Indonesia Berdikari.

Krisnawati, A. (2013). Penerimaan perempuan terhadap representase model perempuan pada iklan rokok Pall Mall "Light up the Night" dan Sampoerna Mild pada media di Indonesia. Commonline Universitas Airlangga Vol 2 No. 3 Hlm 16-31. Diunduh pada tanggal 7 Juli 2018 dari http://journal.unair.ac.id/download-fullpaperscomm9e841d0dcdfull.pdf

Mangunwijaya, Y.B. (2008). Rara Mendut. Jakarta: Gramedia.

Stanton, R. (2007). Teori fiksi. Yogyakarta: Pustaka Pelajar.

Sukri, S.S. dan Sofwan, R. (2001). Perempuan dan seksualitas dalam tradisi Jawa. Yogyakarta: Gama Media.

Wellek, R. dan Warren, A. (1989). Teori kesusastraan. Jakarta: Gramedia. 